Original Article

\title{
Bacterial diversity in high Andean grassland soils disturbed with Lepidium meyenii crops evaluated by metagenomics
}

\author{
Diversidade bacteriana em solos de prados andinos elevados perturbados por culturas \\ de Lepidium meyenii avaliadas por metagenômica

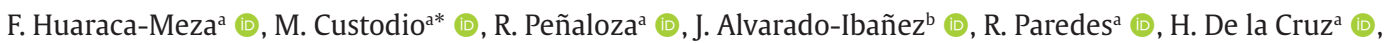 \\ L. Arzapalo ${ }^{\mathrm{a}}$ (D) and F. Lazarte-Parionac (i) \\ aUniversidad Nacional del Centro del Perú, Centro de Investigación en Medicina de Altura y Medio Ambiente, Huancayo, Perú \\ 'Universidad Nacional Intercultural “Fabiola Salazar Leguía” de Bagua, Bagua, Perú \\ 'Universidad Nacional Federico Villareal, Lima, Perú
}

\begin{abstract}
Soil quality is usually determined by its physical-chemical characteristics without taking into account the bacterial communities that play a fundamental role in the chemical decomposition of plant nutrients. In this context, the objective of the study was to evaluate bacterial diversity in high Andean grassland soils disturbed with Lepidium meyenii cultivation under different gradients of use (first, second and third use) and crop development (pre-sowing, hypocotyl development and post-harvest). The sampling was carried out in the Bombón plateau in the central Andes of Peru, during the rainy and low water seasons, by the systematic method based on a specific pattern assigned in a geometric rectangular shape at a depth of $0-20 \mathrm{~cm}$. The characterization of the bacterial communities was carried out through the metagenomic sequencing of the 16S rRNA. 376 families of bacteria were reported, of which it was determined that there was a significant change in bacterial composition and distribution in relation to use pressure. There were no major changes due to the development of Lepidium meyenii. The families most sensitive to use pressure and soil poverty indicators were Verrucomicrobiaceae, Acidobacteraceae and Aakkermansiaceae.
\end{abstract}

Keywords: soil, bacterial diversity, metagenomics, $16 \mathrm{~S}$ rRNA, Lepidium meyenii.

\begin{abstract}
Resumo
A qualidade do solo é normalmente determinada pelas suas características físico-químicas sem ter em conta as comunidades bacterianas que desempenham um papel fundamental na decomposição química dos nutrientes das plantas. Neste contexto, o objetivo do estudo foi avaliar a diversidade bacteriana em solos de prados andinos elevados perturbados pelo cultivo de Lepidium meyenii sob diferentes gradientes de utilização (primeira, segunda e terceira utilizações) e desenvolvimento das culturas (pré-semeadura, desenvolvimento do hipocótilo e póscolheita). A amostragem foi realizada no planalto de Bombón, nos Andes centrais do Peru, durante as estações das chuvas e das águas baixas, pelo método sistemático baseado num padrão específico atribuído em forma geométrica retangular a uma profundidade de $0-20 \mathrm{~cm}$. A caracterização das comunidades bacterianas foi realizada através da sequenciação metagenômica do rRNA 16S. Foram relatadas 376 famílias de bactérias, das quais se verificou uma alteração significativa na composição e distribuição bacteriana em relação à pressão de utilização. Não se registaram grandes alterações devido ao desenvolvimento do Lepidium meyenii. As famílias mais sensíveis à utilização de indicadores de pressão e pobreza do solo foram as Verrucomicrobiaceae, Acidobacteraceae e Aakkermansiaceae.
\end{abstract}

Palavras-chave: solo, diversidade bacteriana, metagenômica, 16S rRNA, Lepidium meyenii.

\section{Introduction}

Microorganisms constitute two-thirds of the soil's biological diversity and therefore play a vital role in regulating ecological processes and the biogeochemical cycle (Amundson et al., 2015). The biological activity of the soil and the composition of the communities are influenced by natural factors such as water, type of vegetation, quality of organic matter, availability of nutrients, soil $\mathrm{pH}$, soil type and climate, as well as by anthropogenic factors such as agriculture and livestock (Carini et al., 2016; Hsu et al., 2019). However, soil pH is considered to be the most important factor influencing the structure of the microbial community (Sun et al., 2015).

The high global demand for "superfoods" since 2012, especially from the Asian market (Beharry and Heinrich,

*e-mail: mcustodio@uncp.edu.pe

Received: June 27, 2020 - Accepted: November 30, 2020 
2018), drove land use change in the central Andes of Peru. In fragile ecosystems such as high Andean grasslands, they have been replaced by monocultures with high nutritional and functional demands such as Lepidium meyenii (maca) (Yaranga et al., 2014), displacing high Andean grasslands that play an important socio-economic role for livestock societies, wildlife livelihoods and important environmental services (Caro et al., 2014).

Monocultures influence the reduction of bacterial diversity due to inadequate soil management, plowing and non-rotation of crops (Myrold et al., 2014). Mainly, plowing causes changes in redox potential and water content, which changes oxygen ratios and the loss of many bacteria species, because anaerobic zones are destroyed (Tang et al., 2017). Therefore, non-agricultural soil is characterized by an abundance of anaerobic bacteria five times greater than that of aerobic bacteria (Handelsman et al., 1998).

The lack of bacterial diversity in agricultural soils is another cause of natural regeneration (Amundson et al., 2015). Therefore, determining the bacterial composition is of great importance within an ecological restoration program; since, problems of land use change lead to the inability to recover the satisfactory level of fertility (Daniel, 2005). Therefore, it is necessary to know new ways of measuring biological fertility indicators, for example, microbial biomass, basal respiration and microbialenzymatic activities (Wolińska et al., 2018).

The latest techniques for the analysis of microbial diversity use direct metagenomic sequencing for the evaluation of their offspring, which provides a genotypic expression of the microorganisms (Handelsman et al., 1998). Currently, through metagenomic tools, it is possible to acquire information about a huge group of bacteria called viable but non-cultivable, which usually comprises 97-99\% of the bacteria in the soil (Hernandez et al., 2010; Shamim et al., 2017). Microbial indicators of soil biological quality are more specific and sensitive to changes in land use and use pressure (Alvarez-Yela et al., 2017; Zafra et al., 2016). In addition, operational taxonomic units (OTU) are significantly reduced in arable soils compared to uncultivated sites (Wolińska et al., 2018).

Previous studies have shown that the genesis of the soil influences the bacterial structure and its colonization preferences. Consequently, finding bacterial indicators by means of metagenomics would make it possible to determine the degree of soil disturbance (Wolińska et al., 2018). In this sense, the objective of the study was to analyze the composition of bacterial communities at molecular level of disturbed soils with maca crops according to the factors pressure of use (first use, second use and third use) and crop development (pre-sowing, development of hypocotyl and post-harvest).

\section{Material and Methods}

\subsection{Study area}

The study was carried out on the Bombón plateau in the central Andes of Peru, at an altitude of 4105 m.a.s.l. The selection of the sampling sectors was for convenience in compliance with the required parameters (use pressure and start of the agricultural season), because the growing period of maca is eight months (Figure 1). The analysis was carried out during the rainy

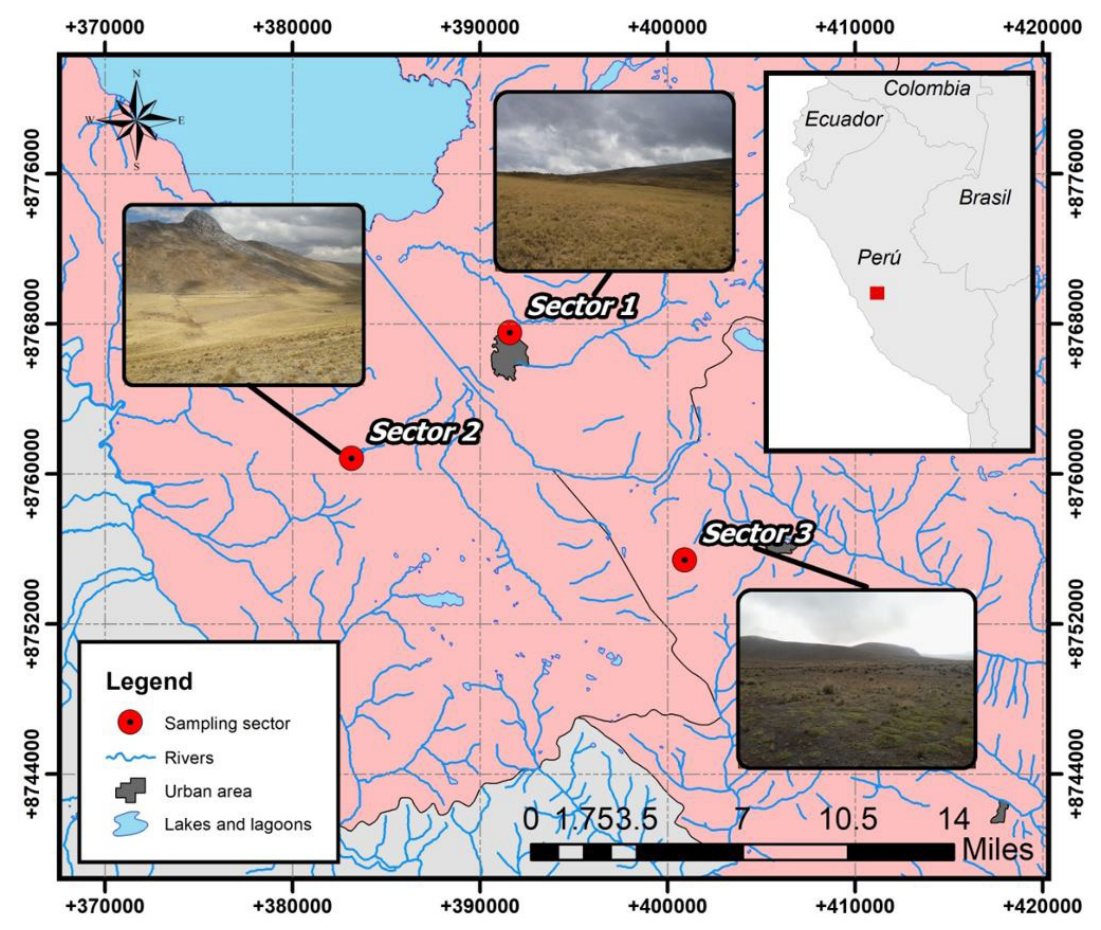

Figure 1. Map of the location of the sampling sectors on the Bombón plateau, Junín. 
season and the beginning of the dry season. The coding of the sampling sectors was based on the factors of pressure of use and sampling period, having both three levels. The use pressure was formed by the levels $1 \mathrm{U}$, $2 \mathrm{U}$ and $3 \mathrm{U}$ (first use, second use and third use); while, the sampling period by the levels of PS, $\mathrm{U}$ and $\mathrm{PH}$ (pre sowing, up growth y post-harvest).

The sampling was carried out in four sectors by the systematic method based on a specific pattern assigned in a rectangular geometric way at a depth of $0-20 \mathrm{~cm}$. Five points were selected to collect a sample composed of one kilogram of soil in each sector, with a minimum of 1 ha of cultivation. The collection of samples was done before planting, during the development of the hypocotyl and the post-harvest in the four sectors, obtaining 12 samples. Finally, the soil samples were conditioned and transported in a refrigerated cooler. In the laboratory the samples were stored at $-50{ }^{\circ} \mathrm{C}$ until the time of analysis.

\subsection{Metagenomic analysis of bacterial DNA from soil}

Metagenomics analysis aims to obtain sequences of the genome of the different bacteria that make up a community, extracting and analyzing their DNA globally.

\subsubsection{DNA extraction}

There are several techniques for the extraction of DNA from different samples. The CTAB method (Doyle and Doyle, 1987) was used for this work. The presence and performance of DNA was analyzed by electrophoresis (Figure 2) for each soil sample.

\subsubsection{Amplification and sequencing of soil DNA}

Immediately, each bacterial DNA sample from the soil was amplified in duplicate by targeting the bacterial $16 \mathrm{~S}$ rRNA gene using PCR amplification, based on classical and next-generation sequences (Figure 3 ). The process is detailed in Figure 4 (green rectangular shapes).

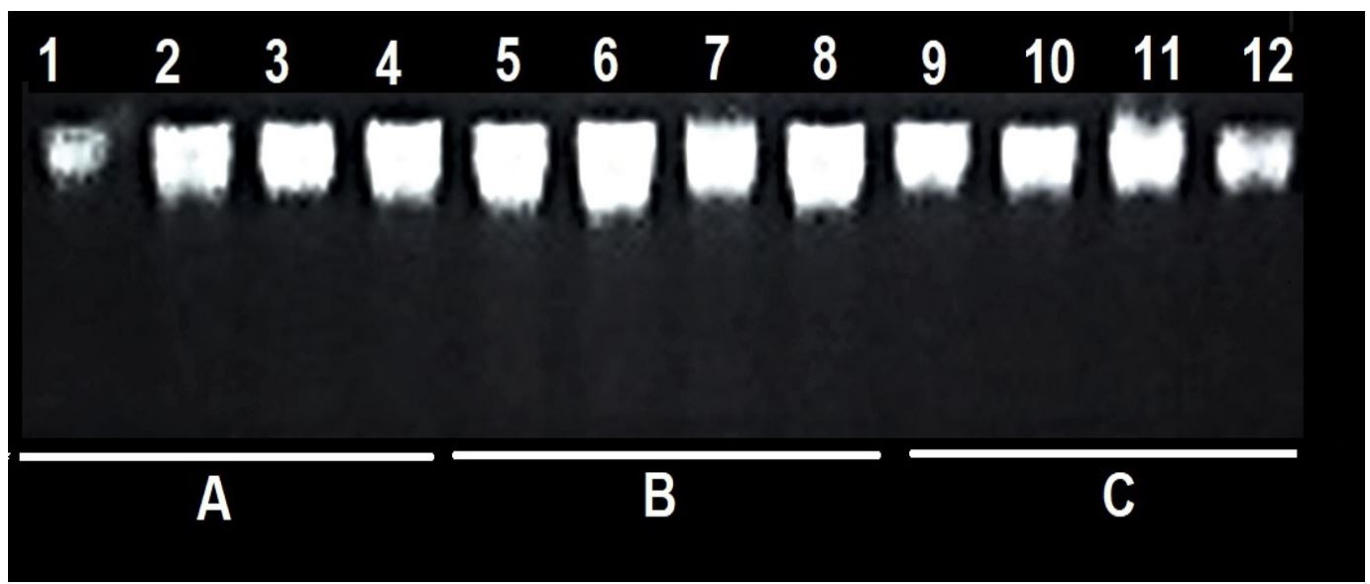

Figure 2. Good quality DNA samples from bacterial populations divided by sampling time factor in soils with pre-sowing levels (A), Lepidium meyenii hypocotyl development (B) and post-harvest (C).

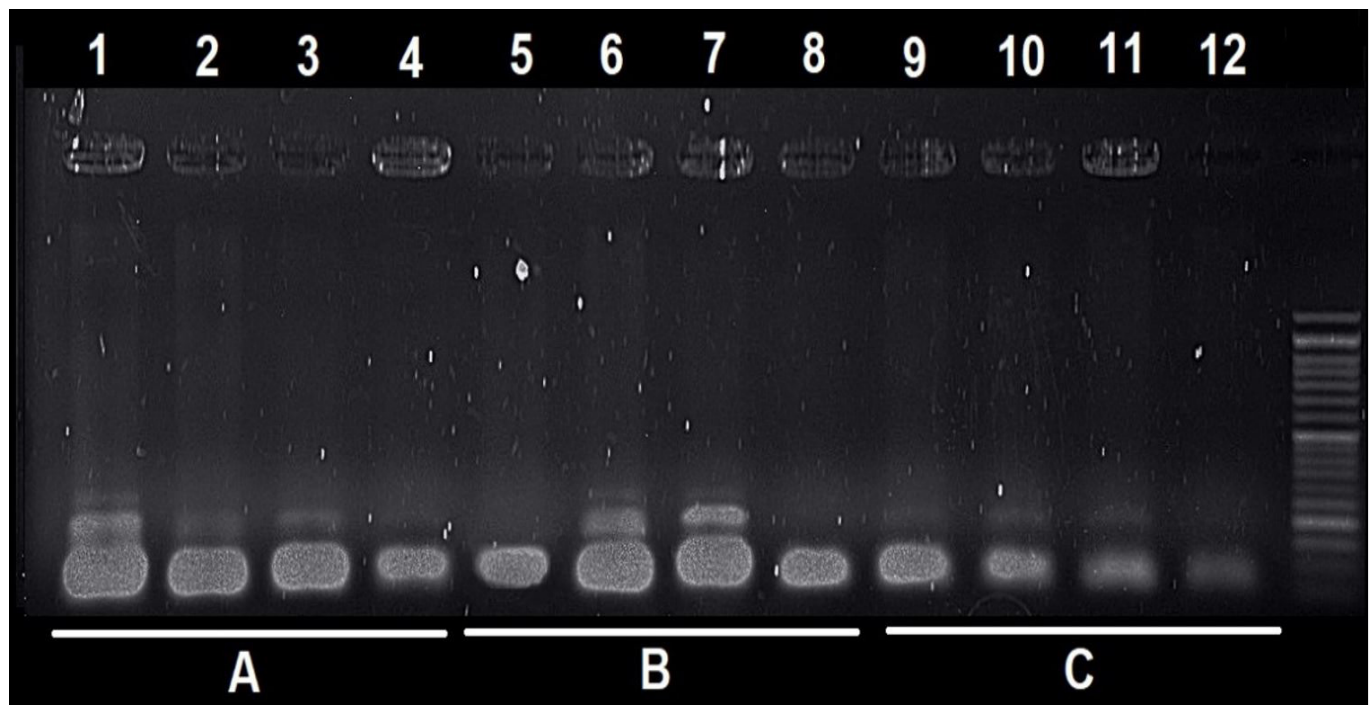

Figure 3. Band migration in bacterial populations according to the V3 - V4 region of the $16 \mathrm{~S}$ bacterial rRNA genes, for the 12 samples divided by the sampling time factor in soils with pre-sowing levels (A), Lepidium meyenii hypocotyl development (B) and post-harvest (C). 


\subsection{Processing of sequenced data}

Raw sequences of all soil samples were processed using various computer tools on the Galaxy platform (Giardine et al., 2005). Paired reads were assigned based on their unique barcodes. The sequences were analyzed using the QIIME software package (Quantitative Insights Into Microbial Ecology, version 1.8.0) (Caporaso et al., 2010), the processes are shown in Figure 4 (red rectangular shapes). The species identified in each soil sample were analyzed using phylogenetic diversity (PD) and richness with the whole tree phylogenetic diversity metric. High quality sequences were grouped into operational taxonomy (OTU) with $97 \%$ sequence similarity.

\subsection{Data analysis}

The data was processed with the CANOCO V5 software. The Bray-Curtis similarity coefficient, applied to taxonomic data transformed to its square root, was calculated to compute a similarity matrix, which generates the nonmetric multidimensional scale (MDS) ordination (Michie, 1982; Malavasi et al., 2004). A principal coordinate analysis (PCoA) was performed to determine whether the patterns observed in the data support the division of the soil samples into the specific groups by generating a co-phenetallic correlation coefficient dendrogram. (Pavoine et al., 2004). Due to the small number of observations, clusters in the dendrogram were considered with a good representation of the dissimilarity matrix with a value close to 1 (Clarke et al., 2016) and thus distinguish biotopes that share the same bacterial community structure and allow us to determine the SIMPER analysis in relation to established groups.

The diversity parameters were evaluated according to the non-parametric Shannon-Wiener diversity index ( $\left.\mathrm{H}^{\prime}\right)$, the Hill Number (N2) and the count of number of families. Percentage similarity analysis (SIMPER) on biological variables was used to evaluate the average percentage of intra-group similarity (defined by an appropriate co-phenetic correlation coefficient rho >0.8) and the average percentage of inter-group dissimilarity (i.e., between sampling areas), allowing evaluation of which families contribute to the similarity or difference between the clustered data (Dawson et al., 1992). The analysis of similarity profiles (SIMPROF) of the families that contributed $40 \%$ of the dissimilarities was used to determine the optimal value of $\mathrm{k}$ groups in which families should be grouped based on their distribution and abundance (Smale et al., 1993), facilitating the interpretation of the groups of families in the dendogram.

\section{Results}

Figure 5 shows the distribution of observations on the perceptual multidimensional non-metric scaling map (non metric MDS), according to use pressure and sampling period factors. The similarity profile analysis (SIMPROF) shows a significant factorial effect of the use pressure with $75 \%$ similarity of the configuration of the families in general. The sampling period factor effect has a low contribution to household distributions since they share a similarity in distribution and type of households close to $85 \%$ in their co-phenetic correlation coefficient. The study considered 6 clusters with a co-phenetic correlation coefficient according to Bray Curtis distances of $90 \%$ in the SIMPROF analysis with a significance level of 0.05 .

Cluster 1 is formed by two samples belonging to soils of the control field with different sampling periods; the sample of the control field before sowing (Control PS), comes from soils that were never disturbed by any crop, and the sample of the control point during the development of the hypocotyl (Control U) that share similarities at $85 \%$. Cluster 2 has the post-harvest control sample (PH control) that shares similarity of distribution and family bacterial conformation of $80 \%$, compared to the samples from the same field in different sampling periods. It is observed that the bacterial structure changed significantly at the end of the hypocotyl development period in fields unpolluted by anthropogenic activities except for South American camelid grazing. While, in the first two sampling periods of planting and development of the hypocotyl in the intermediate period, the bacterial structure does not seem to suffer a significant change (rho Spearman $<85 \%$ ) in its composition and number of families. Indicating that, for a field disturbed for the first time, the composition of families and number of individuals changes by $20 \%$ before

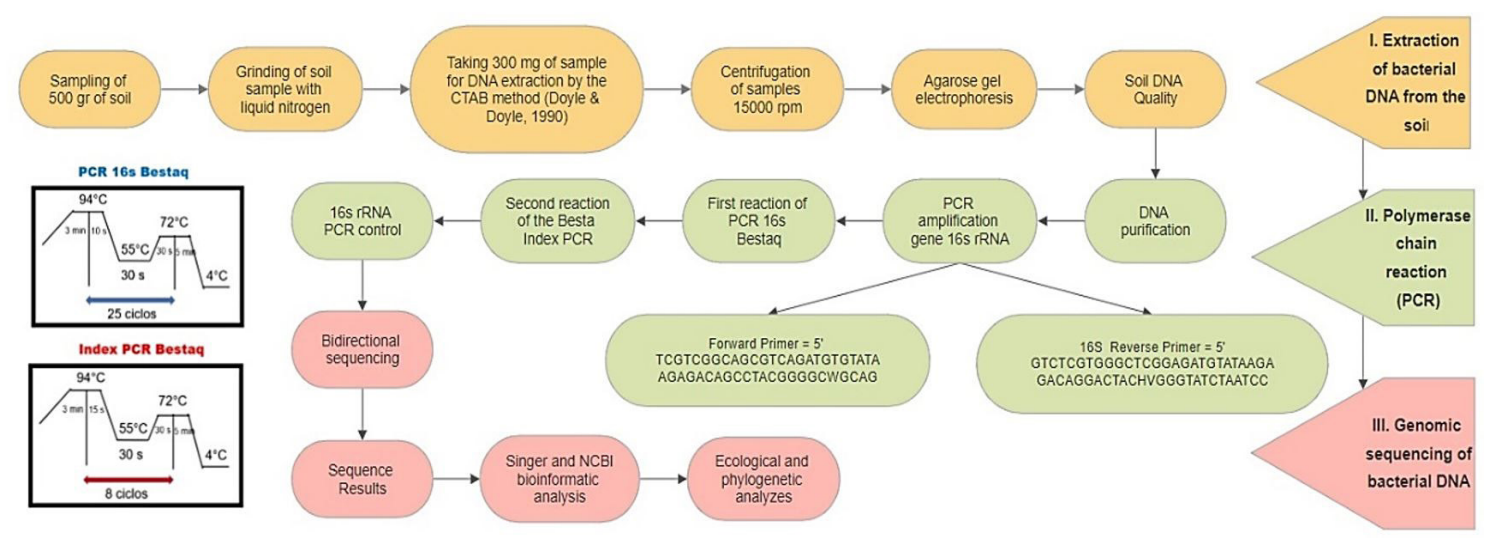

Figure 4. Diagram of the processes for the metagenomic analysis of soils I. DNA metagenomic extraction, II. Polymerase chain reaction, III. Genomic sequencing of bacterial DNA (Modified from Hernández et al., 2010; Yang et al., 2018). 
and after cultivation. However, as a result of increased land use pressure (more annual crops), bacterial diversity changes radically according to their composition and distribution. Compared to a one-time land use pressure the differences at a two- or three-time higher land use pressure are $20 \%$ unequal to the familiar configuration of changing bacteria occurring in the control field. Clusters 3 , 4 and 5 show similarities of $85 \%$, with $15 \%$ dissimilarities especially in fields with all use pressures for annual crops. Significantly different distributions were found before and after cultivation, with a tendency to maintain the bacterial composition for up to the third annual cycle prior to cultivation. Finally, cluster 6 is made up of samples from fields with "three times" use pressure of the final stages of development of the hypocotyl and post-harvest, with a percentage of dissimilarity compared to the field with "two times" use pressure of $15 \%$.

Figure 6 shows the analysis of principal coordinates (PCO), where the distribution of families at $40 \%$ of general contribution and affinity to the coordinates can be seen. The contribution percentages of coordinates 1 and 2 were $54.58 \%$ and $25.63 \%$ of explanatory variation, respectively. The distribution of the first coordinate was influenced by Acidobacteriaceae, Isosphaeraceae, Acholeplasmataceae, Methylocystaceae and Acetobacteraceae, mainly. Cluster 1 tends to have low concentrations of these families in relation to the other two groups due to the effect of usage pressure. This behavior indicates that these families develop easily in soils that are significantly pressured. However, the presence of Flavobacteriaceae in these control soils is significant. The analysis for this group

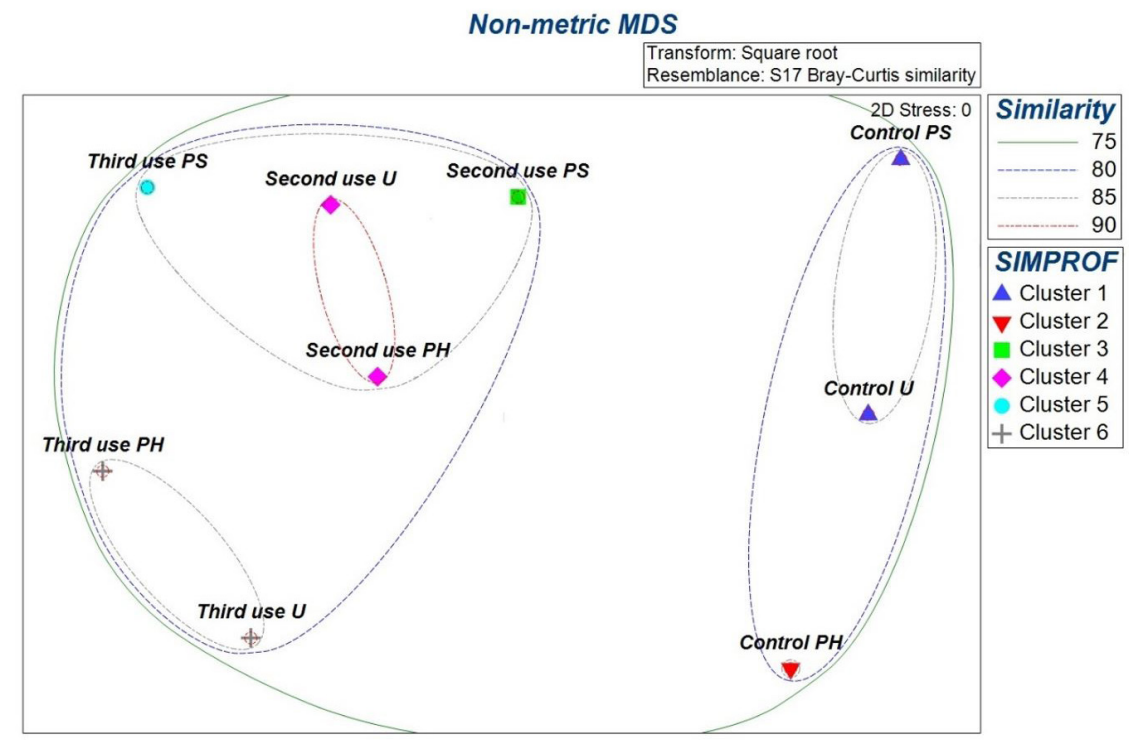

Figure 5. Non-metric MSD and cluster analysis of sampling sectors divided by use pressure and sampling period factors.

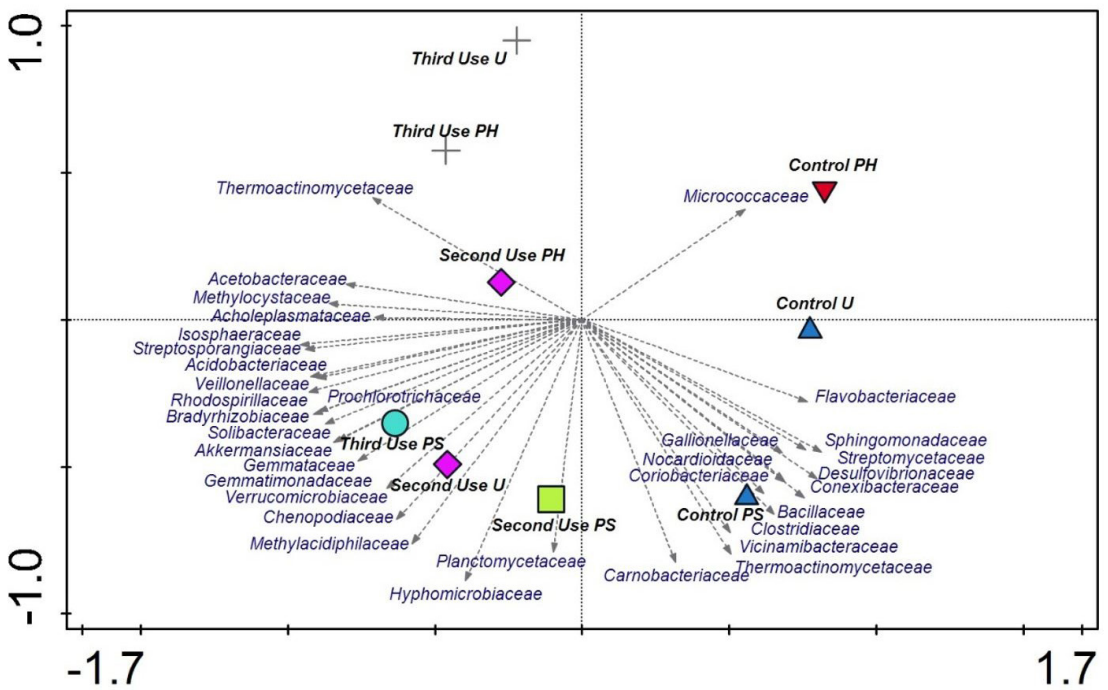

Figure 6. Analysis of principal coordinates of sampling sectors according to the distribution of bacterial families reported at $40 \%$ contribution according to SIMPER analysis. 
also shows that $20 \%$ of dissimilarity in control field soils is influenced by Planctomycetaceae, Hyphomicrobiaceae and Carnobacteriaceae, since these tend to increase as hypocotyl develops in fields with "first use" or control use pressure, mainly. As long as the soil is not disturbed by crops there will be a tendency for these families to dominate, and the composition of the Micrococcaceae will be reduced as the crop develops.

The perceptual map also shows that areas whose use pressure was more than twice as high for maca cultivation determine changes in the composition of families and number of individuals. Fields with a use pressure of twice tend to have a similarity of bacterial families with a cophenetic coefficient of $85 \%$, including the sample that comes from the field whose use pressure was three times before planting, that is, apparently the resting time of the soil influences the bacterial diversity significantly, since the cultivation characteristic is annual, and has a growth period of eight months. Clusters 2, 3 and 4 include all fields with second and third pre-sowing soil use with a co-phenolic coefficient of $85 \%$, differentiated from the samples of fields with three uses by the families Verrucomicrobiaceae, Chenopodiaceae, Methylacidiphilaceae, Planctomycetaceae and Hyphomicrobiaceae with higher frequencies and the families Thermoactinomycetaceae as the main representatives in fields with third use in the final period of hypocotyl development. Figure 6 indicates that the use pressure for cluster 6 with a co-phenolic coefficient of $85 \%$, tends to have a dissimilarity of $15 \%$ of the field cluster with two uses.

The cluster analysis indicates that only the effect of use pressure is an indicator that should be taken into account in a meaningful way for the analysis of the loss of soil diversity by maca cultivation, and that the losses produced by the crop in a short period during its development are minimal. Therefore, any restoration program must take into account that the greater the pressure of soil use, the greater the loss of diversity of bacterial families; that is, the generation of these biotopes determines the bacterial diversity in relation to their composition and abundance.

Table 1 shows that the diversity indices at the family level increased first, followed by a decrease according to the use pressure ("one use" control, two uses and three uses) and sampling period (before planting "PS", development of hypocotyl "U" and post-harvest "PH"). The number of micro-organisms in soils with one use and pre-sowing (PS control) decreased dramatically as the maca crop followed its vegetative development (U control and PH control). Soil microorganisms with "second use" pressure show a significant recovery of their abundance to decrease in post-harvest. Similar behavior is shown by soils with "third use" pressure. A trend of loss in the number of individuals is observed as the crop develops. In a standard context of loss of essential nutrients for bacteria it is translated in a loss of diversity to the first use of virgin soils. Soils with "second use" pressure present configurations in the development of bacteria very different from those that occurred in field one, since an increase in the number of individuals is observed when the crop is in full development and again in the post-harvest the number of microorganisms is significantly reduced. The results show that after the first use of the soil, the surviving bacteria enter into competition with new individuals, as shown by the vectors and indicators of the PCO analysis. In soils with "third use" pressure, significantly higher values of the number of microorganisms are observed due to the natural competitiveness and demographic explosion of each of the new families. Diversity indices such as the Shannon-Wiener index corroborate this distribution as they vary across all the soils evaluated in relation to their specific diversity. Values range from 4.15 to 4.4 and indicate that specific diversity varies by effect of use pressure factor. The results reveal that the soils evaluated have a high diversity of families being higher in the areas that had a single "control" use pressure, regardless of the sampling period, before, during or after cultivation. However, in soils with higher "third use" pressure the microbial diversity started to decrease, as well as the total number of microorganisms. The Simpson indices show a tendency to have high values independent of the use pressure and sampling period.

The distribution of the Hill index, whose values are more robust to changes in the number of species and super abundances, indicates that the distribution of species across all samples due to the interaction of the use pressure and sampling period factors tend to decrease as more use pressure is exerted. The values range from 42.7 as the highest value for the soils of the pre-sowing control field, showing that there is an equilibrium in the distribution of the bacteria families. While as usage pressure increases the Hill index decreases showing that there is apparently a dominance of certain families as usage pressure increases.

Table 1. Bacterial diversity indices at family level in sampling points according to interaction of factors pressure of use and sampling period.

\begin{tabular}{lccccccccc}
\hline $\begin{array}{c}\text { Diversity } \\
\text { indices }\end{array}$ & $\begin{array}{c}\text { Control } \\
\text { PS }\end{array}$ & $\begin{array}{c}\text { Control } \\
\mathbf{U}\end{array}$ & $\begin{array}{c}\text { Control } \\
\text { PH }\end{array}$ & $\begin{array}{c}\text { Second } \\
\text { use PS }\end{array}$ & $\begin{array}{c}\text { Second } \\
\text { use U }\end{array}$ & $\begin{array}{c}\text { Second } \\
\text { use PH }\end{array}$ & $\begin{array}{c}\text { Third } \\
\text { use PS }\end{array}$ & $\begin{array}{c}\text { Third } \\
\text { use U U }\end{array}$ & $\begin{array}{c}\text { Third } \\
\text { use PH }\end{array}$ \\
\hline Dominance_D & 0.02 & 0.02 & 0.03 & 0.03 & 0.03 & 0.03 & 0.03 & 0.03 & 0.03 \\
Simpson_1-D & 0.98 & 0.98 & 0.97 & 0.97 & 0.97 & 0.97 & 0.97 & 0.97 & 0.97 \\
Shannon_H & 4.40 & 4.44 & 4.34 & 4.25 & 4.06 & 4.21 & 4.13 & 4.24 & 4.14 \\
Evenness_E & 0.25 & 0.25 & 0.24 & 0.21 & 0.18 & 0.21 & 0.19 & 0.22 & 0.20 \\
Margalef & 28.29 & 30.16 & 28.78 & 28.79 & 28.01 & 28.54 & 28.02 & 28.78 & 28.10 \\
N2 Hill & 42.7 & 42 & 38.5 & 32.6 & 34.5 & 29.1 & 33.6 & 41.1 & 33.4 \\
Families & 326 & 338 & 312 & 332 & 323 & 321 & 326 & 319 & 314 \\
Individuals & 97492 & 71293 & 49354 & 98303 & 98483 & 74041 & 108942 & 62902 & 68817 \\
\hline
\end{tabular}


Furthermore, during the development of maca cultivation the proportionality of the bacteria families tends to change especially in the period of third use of the soils for cultivation. The values of the Margalef index tend to have the same behavior as the indicators by the Simpson index since there are apparently no significant differences determined by the interaction of the use pressure and sampling period factors. However, the Evenness index that quantifies the numerical equality of the community at the sampling points indicates that there is no trend due to the effect of the sampling period, but there is due to use pressure since there is greater equity in the fields of first use (control).

There were 376 families registered; of which, representative families showing a $40 \%$ contribution according to the SIMPER analysis were considered, grouping 34 families (Table 2). Cluster 5, which is made up of fields with "third use" pre-sowing pressure, has greater

Table 2. SIMPER analysis of reported bacteria families according to groups provided by the cluster analysis.

\begin{tabular}{|c|c|c|c|c|c|c|c|c|c|}
\hline Family & 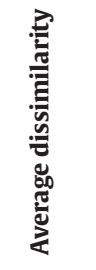 & 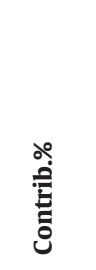 & 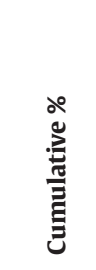 & 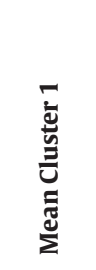 & 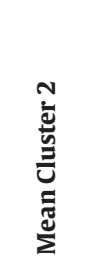 & 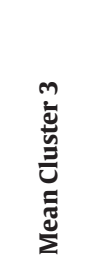 & 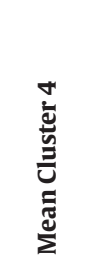 & 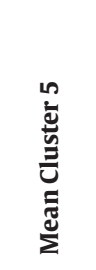 & 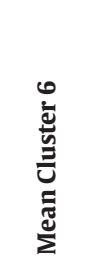 \\
\hline Acidobacteriaceae & 0.536 & 2.946 & 2.946 & 22.600 & 15.200 & 56.000 & 71.300 & 92.600 & 66.300 \\
\hline Verrucomicrobiaceae & 0.4752 & 2.61 & 5.555 & 45.1 & 31.7 & 90.9 & 91.1 & 79.6 & 52 \\
\hline Thermoactinomycetaceae & 0.454 & 2.493 & 8.049 & 8.97 & 7 & 23.6 & 28.1 & 64.5 & 58 \\
\hline Akkermansiaceae & 0.3966 & 2.178 & 10.23 & 18.5 & 13.3 & 55.8 & 59.6 & 61 & 38.7 \\
\hline Solibacteraceae & 0.3356 & 1.843 & 12.07 & 34.1 & 26.8 & 61 & 66.7 & 71.3 & 55 \\
\hline Vicinamibacteraceae & 0.2793 & 1.534 & 13.6 & 74.7 & 51.5 & 68.5 & 50.5 & 50 & 38.5 \\
\hline Bradyrhizobiaceae & 0.2474 & 1.359 & 14.96 & 38.9 & 35.2 & 67 & 60 & 67.5 & 52.1 \\
\hline Isosphaeraceae & 0.242 & 1.329 & 16.29 & 23.5 & 19.3 & 38.7 & 44.6 & 54.2 & 43.4 \\
\hline Gemmataceae & 0.242 & 1.329 & 17.62 & 48.9 & 33.7 & 57.3 & 63.9 & 74.3 & 59.7 \\
\hline Streptosporangiaceae & 0.2319 & 1.274 & 18.89 & 17.7 & 12.8 & 33.6 & 40.1 & 46.3 & 34.4 \\
\hline Conexibacteraceae & 0.2301 & 1.264 & 20.16 & 75 & 65 & 67.9 & 55.2 & 51.9 & 46.3 \\
\hline Nocardioidaceae & 0.2142 & 1.176 & 21.33 & 64.2 & 53.5 & 51 & 43.6 & 44.8 & 35.6 \\
\hline Gemmatimonadaceae & 0.1986 & 1.091 & 22.42 & 54.2 & 43.2 & 68.1 & 61.3 & 77.5 & 59.2 \\
\hline Acholeplasmataceae & 0.1956 & 1.074 & 23.5 & 4.04 & 1.73 & 7.87 & 14.5 & 32.4 & 18.8 \\
\hline Methylocystaceae & 0.1843 & 1.012 & 24.51 & 10.9 & 9.38 & 17.1 & 23.2 & 35.8 & 27.2 \\
\hline Planctomycetaceae & 0.1766 & 0.9695 & 25.48 & 60 & 41.6 & 55.3 & 49.9 & 66.7 & 45 \\
\hline Hyphomicrobiaceae & 0.168 & 0.9225 & 26.4 & 55.9 & 43.6 & 68.4 & 59.5 & 63.3 & 48.4 \\
\hline Prochlorotrichaceae & 0.1606 & 0.882 & 27.28 & 6.39 & 4.58 & 23.4 & 21.5 & 24.5 & 17.4 \\
\hline Acetobacteraceae & 0.1592 & 0.8744 & 28.16 & 15.8 & 13 & 18.4 & 23.4 & 37.7 & 29 \\
\hline Desulfovibrionaceae & 0.1581 & 0.8681 & 29.03 & 32.2 & 22.1 & 25.9 & 17.9 & 15.1 & 11.6 \\
\hline Streptomycetaceae & 0.1553 & 0.8526 & 29.88 & 45.8 & 36.1 & 35.6 & 32.6 & 27.9 & 24.9 \\
\hline Chenopodiaceae & 0.1551 & 0.8518 & 30.73 & 15.1 & 8.94 & 28.1 & 27.5 & 26.5 & 14.7 \\
\hline Veillonellaceae & 0.1544 & 0.8478 & 31.58 & 7.54 & 4.8 & 15.6 & 22.3 & 25.7 & 18.6 \\
\hline Clostridiaceae & 0.1452 & 0.7975 & 32.38 & 30.6 & 24.5 & 31 & 21.1 & 17.9 & 13.1 \\
\hline Methylacidiphilaceae & 0.1448 & 0.7949 & 33.17 & 22.6 & 13.4 & 31.7 & 32 & 30.8 & 19 \\
\hline Micrococcaceae & 0.1381 & 0.7581 & 33.93 & 30.7 & 22.5 & 14.6 & 18.3 & 15.3 & 25.2 \\
\hline Rhodospirillaceae & 0.1367 & 0.7506 & 34.68 & 25.8 & 19.8 & 33.2 & 35 & 42.7 & 33.9 \\
\hline Flavobacteriaceae & 0.1366 & 0.7504 & 35.43 & 26.7 & 15 & 11.7 & 7.52 & 9.85 & 10.4 \\
\hline Thermaceae & 0.1342 & 0.7369 & 36.17 & 29.2 & 20.3 & 28.4 & 20.3 & 20.8 & 11.6 \\
\hline Coriobacteriaceae & 0.1325 & 0.7274 & 36.9 & 18.8 & 11.1 & 17.7 & 5.1 & 5 & 3 \\
\hline Sphingomonadaceae & 0.1322 & 0.726 & 37.62 & 49.8 & 47.1 & 44.9 & 38.4 & 37.6 & 34.1 \\
\hline Gallionellaceae & 0.1246 & 0.684 & 38.3 & 20.4 & 9.49 & 10.4 & 6.84 & 4.12 & 3.26 \\
\hline Carnobacteriaceae & 0.1241 & 0.6815 & 38.99 & 26.9 & 19.7 & 28.1 & 22.7 & 21 & 12.2 \\
\hline Sinobacteraceae & 0.1222 & 0.6711 & 39.66 & 25.2 & 20 & 25.7 & 19.6 & 39.3 & 29.2 \\
\hline
\end{tabular}


dominance of the Acidobacteriaceae families. While clusters 3 and 4 share $85 \%$ similarities, the dominant family is Verrucomicrobiaceae. The family Thermoactinomycetaceae is more dominant in soils with "third use" regardless of crop development. The Akkermansiaceae and Solibacteraceae families tend to have marked frequencies in areas with already disturbed soils. Clusters 1 and 2 which are made up of the control samples tend to have dominances of the families Vicinamibacteraceae, Nocardioidaceae, Planctomycetaceae and Hyphomicrobiaceae, while the Conexibacteraceae are the main ones that differ in terms of their frequency due to the effect of maca cultivation in virgin soil. Group 6 consists of soils from fields that had a "third use" pressure in the final stage of hypocotyl development. There is a tendency of dominance very different from that presented in the first two groups, presenting a greater presence of species of Acidobacteriaceae, Verrucomicrobiaceae, Thermoactinomycetaceae, Solibacteraceae, Bradyrhizobiaceae, Isosphaeraceae and Gemmataceae, mainly. This reveals that the use pressure factor determines the diversity of bacteria families in the soil. Furthermore, clusters 1 and 2, the control sector, indicate that the main family in undisturbed soils is Vicinamibacteraceae. In other words, the loss of this family could be considered as a factor of soil poverty, since this lost diversity responds to the loss of nutrients in the substrate.

The family dendogram indicates 10 groups of significant families ( $p>0.05$ ) that have the same behavior in relation to their distribution and number of individuals in all fields evaluated according to the SIMPROF analysis. From the total of the 34 main families evaluated that contribute $40 \%$ of the total distributions. The cut of the coefficient of co-phenetic was given to an average value of $90 \%$, for the generation of groups as indicated in Figure 7.
An individual analysis of the clusters allowed the identification of the behavior of the main families in each of the sectors evaluated as shown in Figure 8. Group $\boldsymbol{a}$ is made up of the family Thermoactinomycetaceae, which tends to have a greater number of individuals in soils with greater use pressure than in natural conditions but which are not very representative. That is to say, this family could be considered as an indicator of soil poverty since, with greater use pressure, there is a greater frequency of this family. Group b, formed by the families Akkermansiaceae, Methylacidiphilaceae and Verrucomicrobiaceae shows that these families develop in soils where the use pressure increases to "twice" but tend to disappear in soils where the use pressure is "three times". Group c groups the families Bradyrhizobiaceae, Gemmataceae, Gemmatimonadaceae and Rhodospirillaceae which have the same distribution and behavior, with the "twice" use pressure having the highest values. The group $\mathbf{d}$ formed by the families Acidobacteriaceae, Isosphaeraceae, Solibacteraceae and Streptosporangiaceae indicates a higher dominance at higher pressure. The group e formed by the families Sinobacteraceae, Methylocystaceae and Acetobacteraceae, whose dominance increases with the pressure of use as the group $\mathbf{d}$ but with the difference that they tend to have the similarity in their repetitions along all the evaluated soils. Group $\mathrm{f}$ is the indicator of soils with good suitability which is made up of the most representative families in undisturbed soils or healthy soils, whose frequency decreases significantly as a result of use pressure. These families include Bacillaceae, Desulfovibrionaceae, Legionellaceae, Nitrospiraceae, Planctomycetaceae, Polyangiaceae and Vicinamibacteraceae. However, like group f, group $\mathbf{g}$ tends to have the same distribution, but to a lesser extent as an indicator of good soil quality. Group $\mathbf{h}$ tends to have a lesser degree as an indicator of

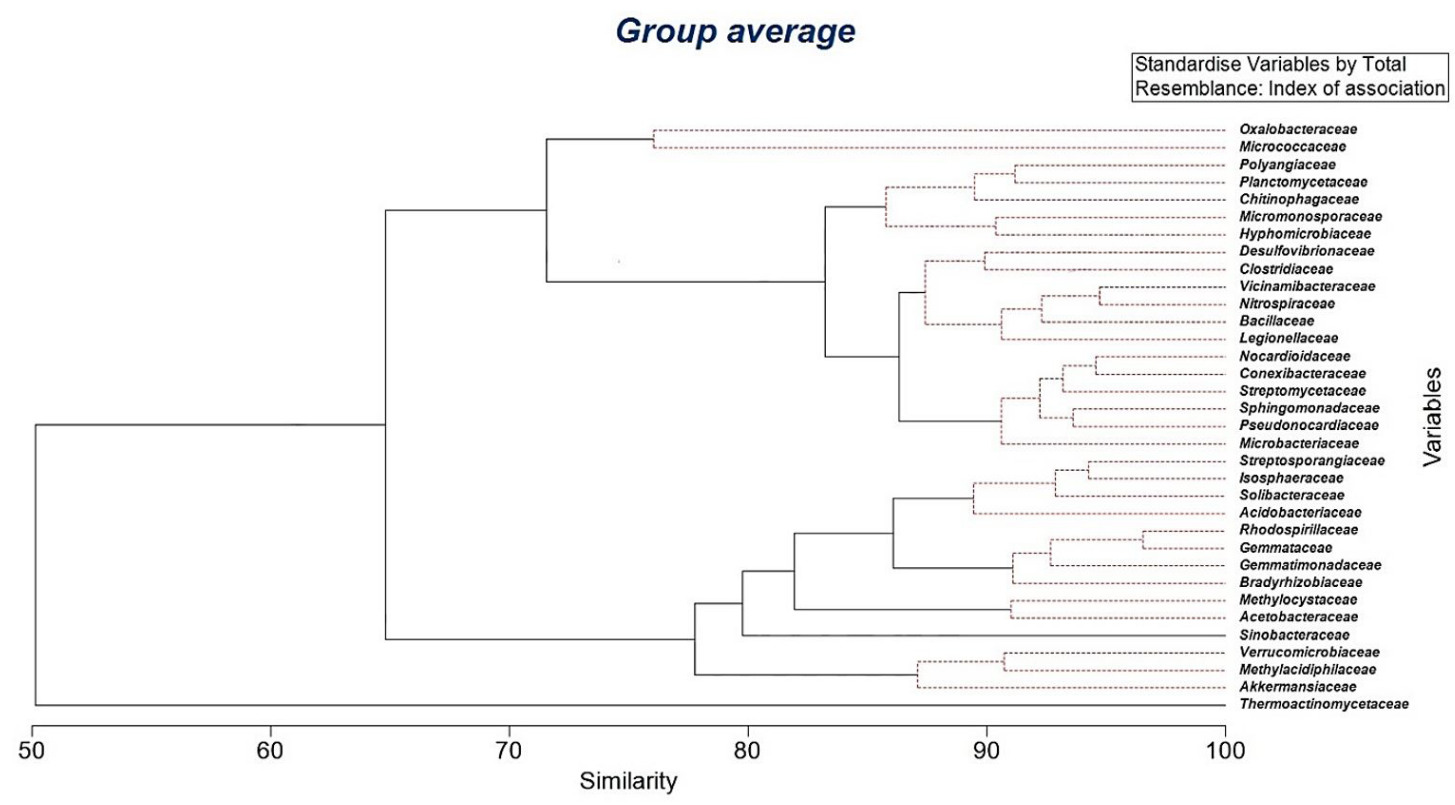

Figure 7. Dendogram of bacterial families at $40 \%$ contribution according to SIMPER analysis in fields disturbed by Lepidium meyenii culture under the effect of the two factors under study (use pressure and sampling period). 


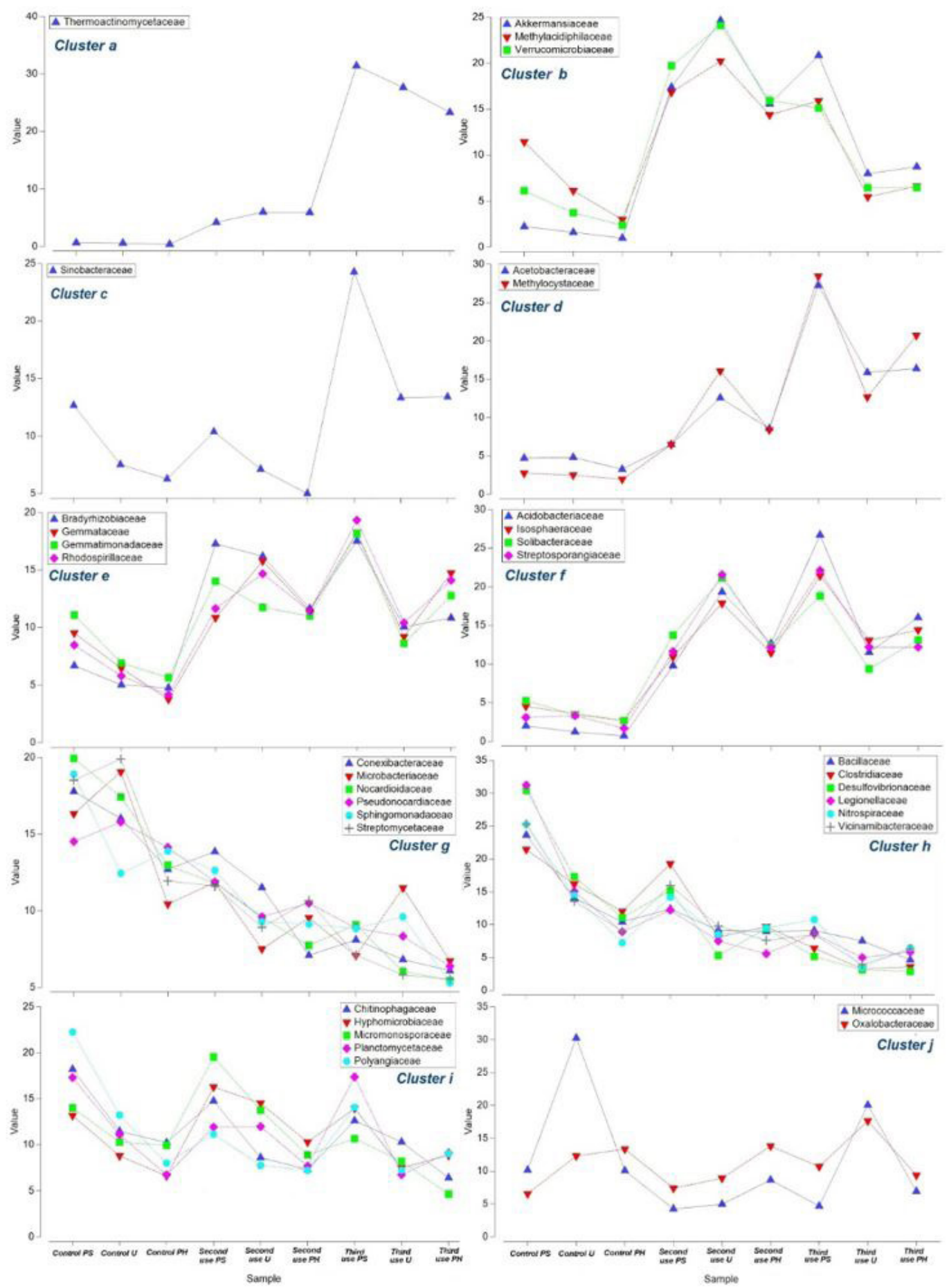

Figure 8. Analysis of the behavior of the clusters of bacterial families significantly differentiated $(\mathrm{p}<0.05)$ according to the SIMPROF analysis at a $40 \%$ contribution of the total of families registered in soils under the factors use pressure and sampling period.

quality of soils of good suitability, since the distribution of the families reported for this group tends to have a similar distribution in all sampling points regardless of use pressure or sampling period. Group i, made up of the families Micrococcaceae and Oxalobacteraceae, shows that these families are more frequent in soils already disturbed with crops in full development. That is, these types of bacteria tend to increase when the maca crop is developing and tend to decrease when the maca crop is harvested in already disturbed soils. 


\section{Discussion}

Maca (Lepidium meyenii Walpers) is an annual herbaceous plant of the family Brassicaceae whose roots are used as a nutritional, functional and nutraceutical food (Yábar, 2019). Although maca production is mainly restricted to the central Andes of Peru, it can be successfully grown in other parts of the world. Also, long-term continuous monoculture systems can trigger negative effects on the composition of soil microbial communities, plant production and quality (Wang et al., 2020). In this study, we focused on the bacterial diversity of soils with continuous use pressure under different sampling periods. The diversity indices of the bacterial communities (Shannon-Wiener, Simpson, etc.) varied according to the use pressure. High values of these indices are observed in soils with "once" use pressure that decrease with the continuous use of soils for maca cultivation. The microbial communities associated with the rhizosphere are also influenced by environmental factors and cultural practices (Yang and Crowley, 2000; Bach et al., 2018). However, previous studies report that root exudates have a negative effect on microbial and plant communities. However, different behaviors of the maca soil microbial communities could be attributed to the presence of certain autotoxic chemicals (Yang and Crowley, 2000).

The individual analysis of the clusters from the highperformance amplicon sequencing data allowed the identification of the behavior of the main families in each of the sectors evaluated. The family Thermoactinomycetaceae consists of 43 fully identified species (Jiang et al., 2019). They are gram-positive, aerobic and thermophilic, where adaptive mechanisms have been developed to perform their metabolic functions at low temperatures (Yao et al., 2014). At low temperatures, bacteria tend to lose their structural rigidity and flexibility of the cell membrane, affecting the performance of catalytic survival reactions. In addition, their membranes contain a higher proportion of unsaturated fatty acids (Kim et al., 2015), making them more resistant to the disturbed environment, as their genes are activated for their survival.

The families Verrucomicrobiaceae and Akkermansiaceae are bacteria that contain only a few species, these come from the order of Microbials. Previous work indicates that the structure and abundance of the family Verrucomicrobiaceae are extremely sensitive to chemical factors related to soil fertility (Navarrete et al., 2015). Other studies suggest that Verrucomicrobiaceae are ubiquitous (Bergmann et al., 2011 ) and abundant (23.5\%) in agroecosystems, and are especially important for crops in the soil (Bergmann et al., 2011; Martínez et al., 2016). On the other hand, Methylacidiphilaceae thrive in the presence of many abiotic factors, such as heavy metals, carbon dioxide and atmospheric nitrogen. However, no information on the microorganism and biotic interactions was found. This could be due to the fact that this microorganism lives in such a hostile environment that it is harmful to most organisms.

The Bradyrhizobiaceae, Gemmataceae, Gemmatimonadaceae and Rhodospirillaceae families registered in our study are characterized by nitrifying nitro-bacteria, such as forced chemolithophy, which must use inorganic mineral salts as an energy source and generally cannot synthesize organic matter. They must oxidize ammonia and nitrites to meet their energy needs and fix inorganic carbon dioxide $\left(\mathrm{CO}_{2}\right)$ to meet their carbon needs. Bradyrhizobiaceae mostly lack motor capacity so they must colonize a surface (gravel, sand, synthetic livelihoods, etc.) for optimal growth. They secrete an essential sticky substance that they use to adhere to. These bacteria oxidize nitrites $\left(\mathrm{NO}_{2-}\right)$ into nitrate $\left(\mathrm{NO}_{3}\right)$. However, Bradyrhizobium bacteria contain strains with high phosphate solubilisation, AAI-producing activities and siderophores (Pascual et al., 2014).

Microorganisms in soils are generally limited by the availability of carbon. However, many of them, such as Acidobacteriaceae, have the ability to degrade a wide range of simple carbon compounds, as well as plant and microbial polysaccharides, including cellulose. Although only a few species have been shown to ferment cellulose. They are acidophilic, slow-growing, and presumably oligotrophic, difficult to isolate (Ivanova et al., 2020). Soils with lower pH values are dominated by acidic bacteria, while the more alkaline soils are mostly inhabited by Bacteroidetes and Actinobacteria (Yang et al., 2018). However, it is known that the Acidobacterium group is common in the soil, that its population decreases with the use of agrochemicals (Kent and Triplett, 2002; Pajares et al., 2018). In addition, it was confirmed that some bacterial families are associated with conventional agriculture (Hu et al., 2014; Pershina et al., 2015).

Soil microorganisms can affect the vegetative development of plants by forming mutualistic and pathogenic interactions and intervening in the nutrient cycle. When populations of microorganisms are reduced, they tend to recover their initial condition and distribution as if they had never been disturbed (Margesin and Zhang, 2013; Cheung et al., 2018). Our Illumina Miseq sequencing results showed that another of the most representative families is the Bacillaceae family which is characterized by its stick shape and by producing endospores. In this family there are useful species, such as those used in flax retting. In nature, especially in the soil, there is a large reserve of spores in a dormant state. In addition, it includes aerobic, anaerobic, and optional anaerobic microorganisms (Huang et al., 2019). The Hyphomicrobiaceae family has many oligocarbophilic species, which thrive only in the presence of low carbon concentrations and cannot grow in high carbon environments such as high Andean soils.

Our study provides the first approach to understanding bacterial diversity in soils disturbed by continuous maca cultivation in the central Andes of Peru. It also reveals the need for further studies in high Andean ecosystems in order to understand their ecology.

\section{Conclusions}

This study shows that understanding the effect of disturbance on soil diversity and bacterial functions can greatly contribute to the improvement of soil quality and the development of sustainable agro-ecosystems. The results indicate that, with increased land use pressure, 
especially for soils whose change of use to low-tech agriculture changes the configuration of the distribution of bacterial families and influences the cycle, nutrient decomposition, soil structure and biological interactions.

Microbial diversity is high and evenly distributed in areas with no or little use pressure. The diversity indices indicate that as more pressure is exerted there is a dominance of families of bacteria characteristic of poor soils such as Acidobacteriaceae, Verrucomicrobiaceae and Akkermansiaceae. Furthermore, during plant development the family of Xanthobacteraceae and Corybacteriaceae are decisive, but not significant. In soils not disturbed by crops we find representative families such as Bacillaceae, Desulfovibrionaceae, Legionellaceae, Nitrospiraceae, Planctomycetaceae, Polyangiaceae and Vicinamibacteraceae as indicators of healthy and quality soils.

Bacterial identification is necessary to determine the function and relationships of bacterial species, as the importance of soil bacterial diversity and its role in ecosystems must be taken into account.

\section{Acknowledgements}

The authors express their gratitude to the General Research Institute of the Universidad Nacional del Centro del Peru for the financing of the study, to the Water Research Laboratory for allowing us to make use of the equipment and materials for this study.

\section{References}

ALVAREZ-YELA, A.C., ALVAREZ-SILVA, M.C., RESTREPO, S., HUSSERL, J., ZAMBRANO, M.M., DANIES, G., GÓMEZ, J.M. and GONZÁLEZ BARRIOS, A.F., 2017. Influence of agricultural activities in the structure and metabolic functionality of paramo soil samples in Colombia studied using a metagenomics analysis in dynamic state. Ecological Modelling, vol. 351, pp. 63-76. http://dx.doi. org/10.1016/j.ecolmodel.2017.02.010.

AMUNDSON, R., BERHE, A.A., HOPMANS, J.W., OLSON, C., SZTEIN, A.E. and SPARKS, D.L., 2015. Soil and human security in the 21st century. Sciencemag, vol. 348, no. 6235, 1261071. http://dx.doi. org/10.1126/science.1261071. PMid:25954014.

BACH, E., WILLIAMS, R., HARGREAVES, S., YANG, F. and HOFMOCKEL, K., 2018. Greatest soil microbial diversity found in micro-habitats. Soil Biology E Biochemistry, vol. 118, pp. 217-226. http://dx.doi. org/10.1016/j.soilbio.2017.12.018.

BEHARRY, S. and HEINRICH, M., 2018. Is the hype around the reproductive health claims of maca (Lepidium meyenii Walp. justified? Journal of Ethnopharmacology, vol. 211, pp. 126-170. http://dx.doi.org/10.1016/j.jep.2017.08.003. PMid:28811221.

BERGMANN, G.T., BATES, S.T., EILERS, K.G., LAUBER, C.L., CAPORASO, J.G., WALTERS, W.A., KNIGHT, R. and FIERER, N., 2011. The underrecognized dominance of Verrucomicrobia in soil bacterial communities. Soil Biology \& Biochemistry, vol. 43, no. 7, pp. 1450-1455. http://dx.doi.org/10.1016/j.soilbio.2011.03.012. PMid:22267877.

CAPORASO, G., KUCZYNSKI, J., STOMBAUGH, J., BITTINGER, K., BUSHMAN, F., COSTELLO, E., FIERER, N., PEÑA, A.G., GOODRICH, J.K., GORDON, J.I., HUTTLEY, G.A., KELLEY, S.T., KNIGHTS, D., KOENIG, J.E., LEY, R.E., LOZUPONE, C.A., MCDONALD, D., MUEGGE, B.D., PIRRUNG, M., REEDER, J., SEVINSKY, J.R., TURNBAUGH, P.J.,
WALTERS, W.A., WIDMANN, J., YATSUNENKO, T., ZANEVELD, J. and KNIGHT, R., 2010. QIIME allows analysis of high- throughput community sequencing data. Nature Publishing Group, vol. 7, no. 5, pp. 335-336. http://dx.doi.org/10.1038/nmeth.f.303. PMid:20383131.

CARINI, P., MARSDEN, P., LEFF, J., MORGAN, E., STRICKLAND, M. and FIERER, N., 2016. Relic DNA is abundant in soil and obscures estimates of soil microbial diversity. Nature Microbiology, vol. 2, 16242. http://dx.doi.org/10.1038/nmicrobiol.2016.242. PMid:27991881.

CARO, C., SANCHEZ, E., QUINTEROS, Z. and CASTAÑEDA, L., 2014. Respuesta de los pastizales altoandinos a la perturbación generada por extracción mediante la actividad de "champeo". Ecología Aplicada, vol. 13, no. 2, pp. 85-95. http://dx.doi. org/10.21704/rea.v13i1-2.459.

CHEUNG, M.K., WONG, C.K., CHU, K.H. and KWAN, H.S., 2018. community structure, dynamics and interactions of bacteria, Archaea and fungi in subtropical coastal wetland sediments. Scientific Reports, vol. 8, no. 1, 14397. http://dx.doi.org/10.1038/ s41598-018-32529-5. PMid:30258074.

CLARKE, K.R., SOMERFIELD, P.J. and GORLEY, R.N., 2016. Clustering in non-parametric multivariate analyses. Journal of Experimental Marine Biology and Ecology, vol. 483, pp. 147-155. http://dx.doi. org/10.1016/j.jembe.2016.07.010.

DANIEL, R., 2005. The metagenomics of soil. Nature Reviews. Microbiology, vol. 3, no. 6, pp.470-478. http://dx.doi.org/10.1038/ nrmicro1160. PMid:15931165.

DAWSON, A., WARWICK, R., CLARKE, R. and BROWN, B., 1992. An analysis of fish community responses to coral mining in the Maldives. Environmental Biology of Fishes, vol. 33, no. 4, pp. 367-380. http://dx.doi.org/10.1007/BF00010949.

DOYLE, J. and DOYLE, J., 1987. A rapid DNA isolation procedure for small quantities of fresh leaf tissue. Phytochemical Bulletin, vol. 12, pp. 11-15.

GIARDINE, B., RIEMER, C., HARDISON, R.C., BURHANS, R., ELNITSKI, L., SHAH, P., ZHANG, Y., BLANKENBERG, D., ALBERT, I., TAYLOR, J., MILLER, W., KENT, W.J. and NEKRUTENKO, A., 2005. Galaxy: a platform for interactive large-scale genome analysis. Genome Research, vol. 15, no. 10, pp. 1451-1455. http://dx.doi.org/10.1101/ gr.4086505. PMid:16169926.

HANDELSMAN, J., RONDON, M.R., BRADY, S.F., CLARDY, J. and GOODMAN, R., 1998. Molecular biological access to the chemistry of unknown soil microbes: a new frontier for natural products. Chemistry E Biology, vol. 5, no. 10, pp. R245-R249. http://dx.doi. org/10.1016/S1074-5521(98)90108-9. PMid:9818143.

HERNANDEZ, R., VELAZQUEZ, I., OROZCO, M. and SANTOYO, G., 2010. Soil Metagenomics: new challenges and biotechnological opportunities. International Journal of Experimental Botany, vol. 79, pp. 133-139.

HSU, R., CLARK, R., TAN, J.W., AHN, J., GUPTA, S., ROMERO, P.A. and VENTURELLI, O., 2019. Microbial Interaction Network Inference in Microfluidic Droplets. Cell Systems, vol. 9, no. 3, pp. 229-242. e4. http://dx.doi.org/10.1016/j.cels.2019.06.008. PMid:31494089.

HU, C., ZHANG, Y., ZHANG, L. and LUO, W., 2014. Effects of microbial iron reduction and oxidation on the immobilization and mobilization of copper in synthesized Fe (III minerals and Fe-rich soils. Journal of Microbiology and Biotechnology, vol. 24, no. 4, pp. 534-544. http://dx.doi.org/10.4014/jmb.1310.10001. PMid:24448165.

HUANG, X., ZHAO, J., ZHOU, X., ZHANG, J. and CAI, Z., 2019. Differential responses of soil bacterial community and functional diversity to reductive soil disinfestation and chemical soil disinfestation. Geoderma, vol. 348, pp. 124-134. http://dx.doi. org/10.1016/j.geoderma.2019.04.027. 
IVANOVA, A.A., ZHELEZOVA, A.D., CHERNOV, T.I. and DEDYSH, S.N., 2020. Linking ecology and systematics of acidobacteria: distinct habitat preferences of the Acidobacteriia and Blastocatellia in tundra soils. PLoS One, vol. 15, no. 3, e0230157. http://dx.doi. org/10.1371/journal.pone.0230157. PMid:32182280.

JIANG, Z., XIAO, M., YANG, L., ZHI, X. and LI, W., 2019. Genome-based taxonomic classification within the family Thermoactinomycetaceae. International Journal of Systematic and Evolutionary Microbiology, vol. 69, no. 7, pp. 2028-2036. http://dx.doi.org/10.1099/ijsem.0.003425. PMid:31066660.

KENT, A.D. and TRIPLETT, E.W., 2002. Microbial communities and their interactions in soil and rhizosphere ecosystems. Annual Review of Microbiology, vol. 56, no. 1, pp. 211-236. http://dx.doi. org/10.1146/annurev.micro.56.012302.161120. PMid:12142496.

KIM, M.C., KIM, T.R., RI, S.Y., JIANG, F., CHANG, X., LIU, Y., REN, L., QIU, X., DENG, S., FANG, C., ZHENG, C. and PENG, F., 2015. Risungbinella pyongyangensis gen. Nov., sp. nov., a mesophilic member of the family Thermoactinomycetaceae isolated from an agricultural soil sample. International Journal of Systematic and Evolutionary Microbiology, vol. 65, no. 8, pp. 2726-2733. http://dx.doi.org/10.1099/ijs.0.000328. PMid:25977282.

MALAVASI, S., FIORIN, R., FRANCO, A., FRANZOI, P., GRANZOTTO, A., RICCATO, F. and MAINARDI, D., 2004. Fish assemblages of Venice Lagoon shallow waters: an analysis based on species, families and functional guilds. Journal of Marine Systems, vol. 51, no. 1-4 pp. 19-31. http://dx.doi.org/10.1016/j.jmarsys.2004.05.006.

MARGESIN, R. and ZHANG, D.C., 2013. Humitalea rosea gen. nov., sp. nov., an aerobic bacteriochlorophyll-containing bacterium of the family Acetobacteraceae isolated from soil. International Journal of Systematic and Evolutionary Microbiology, vol. 63, no. Pt 4, pp. 1411-1416. http://dx.doi.org/10.1099/ijs.0.043018-0. PMid:22821736

MARTÍNEZ, M., LARA, A.J., CADENA, J., SALINAS, Y., RAMÍREZ, H. and ARTEAGA, R., 2016. Rhizospheric microbiota of a mixed crop of corn (Zea mays L. in the Jalisco highlands: descriptive study. Agroproductividad, vol. 9, no. 8, pp. 65-70.

MICHIE, M., 1982. Use of the Bray-Curtis similarity measure in cluster analysis of foraminiferal data. Journal of the International Association for Mathematical Geology, vol. 14, no. 6, pp. 661-667. http://dx.doi.org/10.1007/BF01033886.

MYROLD, D.D., ZEGLIN, L.H. and JANSSON, J.K., 2014. The Potential of Metagenomic Approaches for Understanding Soil Microbial Processes. Soil Science Society of America Journal, vol. 78, no. 1, pp. 3-10. http://dx.doi.org/10.2136/sssaj2013.07.0287dgs.

NAVARRETE, A.A., SOARES, T., ROSSETTO, R., VAN VEEN, J.A., TSAI, S.M. and KURAMAE, E.E., 2015. Verrucomicrobial community structure and abundance as indicators for changes in chemical factors linked to soil fertility. Antonie van Leeuwenhoek. International Journal of General and Molecular Microbiology, vol. 108, no. 3, pp. 741-752. http://dx.doi.org/10.1007/s10482015-0530-3. PMid:26184407.

PAJARES, S., CAMPO, J., BOHANNAN, B. and ETCHEVERS, J., 2018 Environmental Controls on Soil Microbial Communities in a Seasonally Dry Tropical Forest. Applied and Environmental Microbiology, vol. 84, no. 17, pp. 1-19. http://dx.doi.org/10.1128/ AEM.00342-18. PMid:29959251.

PASCUAL, F., BLANCO, S., RAMOS, J. and VAN, P., 2014. The effect of climate on the microbial biogeography of the soil associated with plants in the Sierra Nevada. Journal of Microbiology and Biotechnology, vol. 24, no. 4, pp. 534-544.

PAVOINE, S., DUFOUR, A. and CHESSEL, D., 2004. From dissimilarities among species to dissimilarities among communities: A double principal coordinate analysis. Journal of Theoretical Biology, vol. 228, no. 4, pp. 523-537. http://dx.doi.org/10.1016/j. jtbi.2004.02.014. PMid:15178200.
PERSHINA, E., VALKONEN, J., KURKI, P., IVANOVA, E., CHIRAK, E., KORVIGO, I., PROVOROV, N. and ANDRONOV, E., 2015. Comparative analysis of prokaryotic communities associated with organic and conventional farming systems. PLoS One, vol. 10, no. 12, pp. 1-16. http://dx.doi.org/10.1371/journal. pone.0145072. PMid:26684619.

SHAMIM, K., SHARMA, J. and DUBEY, S.K., 2017. Rapid and efficient method to extract metagenomic DNA from estuarine sediments. 3 Biotech, vol. 7, no. 3, pp. 185. http://dx.doi.org/10.1007/ s13205-017-0846-y. PMid:28664369.

SMALE, M.J., ROEL, B.A., BADENHORST, A. and FIELD, J.G., 1993. Analysis of the demersal community of fish and cephalopods on the Agulhas Bank, South Africa. Journal of Fish Biology, vol. 43, pp. 169-191. http://dx.doi.org/10.1111/j.1095-8649.1993. tb01186.x.

SUN, R., ZHANG, X.X., GUO, X., WANG, D. and CHU, H., 2015. Bacterial diversity in soils subjected to long-term chemical fertilization can be more stably maintained with the addition of livestock manure than wheat straw. Soil Biology \& Biochemistry, vol. 88, pp. 9-18. http://dx.doi.org/10.1016/j.soilbio.2015.05.007.

TANG, L., XIA, Y., WU, X., CHEN, X., ZHANG, X. and LI, H., 2017. Screening and characterization of a novel thermostable lipase with detergent-additive potential from the metagenomic library of a mangrove soil. Gene, vol. 625, pp. 64-71. http://dx.doi. org/10.1016/j.gene.2017.04.046. PMid:28457984.

WANG, S., DONG, L., LUO, Y., JIA, W. and QU, Y., 2020. Characterization of rhizosphere microbial communities in continuous cropping maca (Lepidium meyenii) red soil, Yunnan, China. Archives of Agronomy and Soil Science, vol. 66, no. 6, pp. 805-818. http:// dx.doi.org/10.1080/03650340.2019.1639155.

WOLIŃSKA, A., KUŹNIAR, A., ZIELENKIEWICZ, U., BANACH, A. and BŁASZCZYK, M., 2018. Indicators of arable soils fatigue - Bacterial families and genera: a metagenomic approach. Ecological Indicators, vol. 93, no. May, pp. 490-500. http:// dx.doi.org/10.1016/j.ecolind.2018.05.033.

YÁBAR, V.E., 2019. Maca (Lepidium Meyenii Walpers) andean functional food: bioactives, biochemistry and biological activity. Revista de Investigaciones Altoandinas, vol. 21, no. 2, pp. 139-152. http://dx.doi.org/10.18271/ria.2019.457.

YANG, C.H. and CROWLEY, D.E., 2000. Rhizosphere microbial community structure in relation to root location and plant iron nutritional status. Applied and Environmental Microbiology, vol. 66, no. 1, pp. 345-351. http://dx.doi.org/10.1128/AEM.66.1.345351.2000. PMid:10618246.

YANG, Y., DOU, Y. and AN, S., 2018. Testing association between soil bacterial diversity and soil carbon storage on the Loess Plateau. The Science of the Total Environment, vol. 626, no. 26, pp. 48-58. http://dx.doi.org/10.1016/j.scitotenv.2018.01.081. PMid:29335174.

YAO, S., LIU, Y., ZHANG, M., ZHANG, X., LI, H., ZHAO, T., XIN, C., XU, L., ZHANG, B. and CHENG, C., 2014. Thermoactinomyces daqus sp. nov., a thermophilic bacterium isolated from hightemperature Daqu. International Journal of Systematic and Evolutionary Microbiology, vol. 64, no. Pt 1, pp. 206-210. http:// dx.doi.org/10.1099/ijs.0.055509-0. PMid:24048866.

YARANGA, R., CUSTODIO, M. and ORELLANA, E., 2014. Composition and floral diversity in Andean grasslands in natural postharvest restoration with Lepidium meyenii Walpers. Revista Ambiente \& Água, vol. 9, no. 3, pp. 445-458. http://dx.doi. org/10.4136/1980-993X.

ZAFRA, G., TAYLOR, T.D., ABSALÓN, A.E. and CORTÉS-ESPINOSA, D.V., 2016. Comparative metagenomic analysis of PAH degradation in soil by a mixed microbial consortium. Journal of Hazardous Materials, vol. 318, no. 55, pp. 702-710. http:// dx.doi.org/10.1016/j.jhazmat.2016.07.060. PMid:27484946. 